\title{
CORRESPONDENCE
}

\author{
Inhumanity to man \\ Rita Henryk-Gutt, MRCPSYCH. \\ Polio vaccines and polioviruses \\ J Salk, MD \\ Lithium and thyrotoxicosis \\ J Merry, FRCPSYCH \\ The grateful patient \\ $M$ Knowles, MRCGP \\ R W Beard, FrCOG, and D B Paintin, fRCOG 765 \\ Women who regret sterilisation \\ B Alderman, MRCOG \\ Oestrogen treatment for menopausal \\ flushing \\ G P Mulley, MRCP, and J R A Mitchell, \\ FRCP \\ Oestrogen treatment and endometrial \\ carcinoma \\ A R Feinstein, MD, and R I Horwitz, MD . \\ Strawberry pickers' foot drop \\ Anna M Seppäläinen, MD, and others \\ Exercise-induced asthma \\ H G J Herxheimer, LRCP; J G Heathcote, \\ Liver biopsy in "difficult" jaundice \\ A $N$ Hamlyn, MRCP. \\ More bird lore \\ R A M Scott, FRCGP \\ Salbutamol-induced diabetic \\ ketoacidosis \\ R D G Leslie, MRCP, and P M Coats, MRCOG 768 \\ Skills of the nurse \\ Gwen M Prentice, SRN \\ Tuberculin testing in hospital staff \\ C A Bartzokas, MD \\ Screening children for visual defects \\ G R Brackenridge, FRCPED \\ Shortage of anaesthetists \\ D J D Stevenson, MD. \\ 766

66 \\ Domiciliary oxygen \\ 766 Acute suppurative thyroiditis caused by \\ Pseudomonas aeruginosa \\ M Barnham, MB. \\ Fetal monitoring and fetal deaths in \\ labour \\ C A Thornton, MRCOG \\ Stress incontinence \\ S L R Stanton, FRCS. \\ Spectacle lenses and eye injuries in \\ children \\ D H Larder. \\ Immunisation and brain damage \\ G Schoenewald, MD \\ 766 Late infection after hip replacement \\ R Bayston, MMEDSCI, and R B Zachary, FRCS 770 \\ 767 Malignancy in relatives of \\ "non-responders" to $R h$ antigen \\ I A Cook, FRCPATH, and Sally V Shepherd, \\ MA \\ Urinary incontinence in chi!dren \\ E S Glen, FRCSED. \\ Effect of wholemeal and white bread on \\ iron absorption \\ A R P Walker, DSC, and B F Walker..... . 771 \\ The community physician: will he \\ survive? \\ B T Williams, MD. \\ Antibiotics for presumed viral \\ respiratory infections \\ K R Woodcock, MRCP \\ 769 Treatment of cutaneous larva migrans \\ with local thiabendazole \\ P S E G Harland, MRCP, and others. \\ Death from ischaemic heart disease \\ N J Wald, MRCP, and J I Mann, DM. . . . . 772 \\ 769 \\ Poisoning with antidepressants \\ H Kopera, MD, and H Schenk, MD . . . . 773 \\ 769 "Zip injury" to the penis \\ A C Srivastava, MD \\ Levamisole-induced arthritis \\ P W L Siklos, MRCP \\ Interaction between azapropazone and \\ warfarin \\ J C McElnay, BSC, and P F D'Arcy, DSC . . . 773 \\ 770 Femoral vein thrombosis after total hip \\ replacement \\ 770 J P Bolton, FRCS \\ Place of chlormethiazole in treatment of \\ alcoholics \\ J J Bradley, FRCPSYCH. \\ Acute gastric dilatation in anorexia \\ nervosa \\ O P N Grüner, MD ............. 774 \\ Names of drugs \\ M B Hay, MRCGP. \\ Seniority payments and service in \\ HM Forces \\ W A Jerrett, $M B$. \\ Hospital appointment procedure \\ H E Thomas, FRCP; R W Thomson, FRCS . 775 \\ Status of general practitioners \\ C D Garratt, MRCP. \\ By their fruits ... \\ B O Scott, MRCs. \\ Fees for part-time \\ Government departments \\ J D W Whitney, MRCGP. \\ Which arm squeezes the bag? \\ G E Rose. . .

Correspondents are urged to zurite briefly so that readers may be offered as wide a selection of letters as possible. So many are being received that the omission of some is inevitable. Letters should be signed personally by all their authors.

\section{Inhumanity to man}

SIR,-Your leading article "Inhumanity to man" (3 September, p 591) bitterly castigates psychiatric hospitals for failing to accommodate numbers of mentally disordered offenders; this criticism applies equally, no doubt, to hospitals for the mentally handicapped (subnormal). Two points emerge for discussion of this problem: firstly, whether all mentally disordered offenders are properly placed in psychiatric hospitals; and secondly, the whole problem of the functioning of the large psychiatric hospitals.

For 16 years the medical and nursing staffs of these hospitals have been demoralised and depleted by conflicting instructions, demands, and criticisms. The hospitals have been condemned as disgraceful places, fit only to be pulled down, and exhorted to release into a welcoming community those imprisoned patients for whom further benefit from medical treatment cannot be expected. The hospital staff are then blamed for failing to care for chronically ill patients with whom hardpressed relatives can no longer cope and for those whose social incompetence has led to prison, or wandering, or other unsatisfactory modes of living. The promised community facilities have proved too expensive to provide, yet the mental hospitals are drained of staff and resources to do their work. Psychiatric hospitals are told to open their doors (successfully, for as the numbers of longer-stay patients fall the numbers of readmissions rise, as also does the prison population). Simultaneously they are asked to provide secure facilities for offenders and to care for increasing numbers of mentally frail elderly patients as well as alcoholics, disturbed adolescents, and other categories of patients requiring special services while beds and staff disappear. It is clear that certain groups of mental patients cannot reasonably be contained in general hospital units, and other types of care are needed for them. Sometimes it seems as if society wishes these psychiatric hospitals to disappear from existence but taking with them all the disturbed, disturbing, and socially misfitted elements of the community. Under these pressures it is hardly surprising that nurses working on wards where staffing levels are often inadequate and continuity of care impossible because staff are moved so often are reluctant to look after patients who place them at risk of physical injury.

It must also be recognised that, while many offenders are only so because of treatable mental illness, many others are of delinquent or of violent tendency, or both, regardless of any existing mental disorder; and in other cases the mental disorder may not be responsive to treatment. What of the fears of the other patients in the hospital, the stigma attached to them, and the anxieties of the local residents? Mental hospital patients enjoy the freedom of the facilities of the neighbourhood and may be employed outside hospital. These advantages may well be denied to many if a few patients exhibit disturbing behaviour outside the hospital. Perhaps it would be more realistic to think about hospitals in prisons than prisons within hospitals.

On the wider issue an honest decision needs to be made about the resources which can be allocated to the care of the chronically mentally incapacitated. It must be understood that many of these patients cannot be restored to a condition in which they can live independently but need long-term care in or out of hospital. Psychiatrists and psychiatric nurses are not to blame for the conditions in which they find they have to work and their patients have to live. We will do our best with available resources if we are allowed to select priorities and organise our work accordingly. But if our responsibilities are to be increased and standards improved, then more professional staff will be needed and many hospitals will need building improvements.

The choice is not ours, but neither is all of the blame for the shortcomings of the service which we provide.

Shenley Hospital,

Rita HENRYK-Gutr 